\title{
Effective measures in Sustainable urban mobility plans (SUMPs): Analysis of 10 (successful) European cities
}

\author{
Andraž Hudoklin ${ }^{a}$, Luka Mladenoviča ${ }^{a}$ Mojca Balant ${ }^{a}$, Tom Rye $^{b}$ \\ a Urban Planning Institute of the Republic of Slovenia, Trnovski pristan 2, 1000 Ljubljana, Slovenia \\ ${ }^{b}$ Molde University College (HIMOLDE), Norway
}

\section{ARTICLE INFO}

\begin{tabular}{l}
\hline DOI: $10.31075 /$ PIS.67.04.04 \\
Professional paper \\
Received: $15 / 11 / 2021$ \\
Accepted: 15/12/2021 \\
Corresponding author: \\
andrazh@uirs.si \\
\hline Keywords: \\
Effective measures \\
SUMP \\
Modal shift \\
Road space transformation \\
This article has been presented at the 8th \\
International Conference \\
"Towards a Humane City" \\
11-12 November 2021, N. Sad, Serbia
\end{tabular}

\begin{abstract}
A B S TR A C T
The paper presents results of an analysis of measures implemented in various European cities that have been effective in reducing the share of trips by car and increasing the shares of active mobility and public transportation. Ten cities with a significant modal shift from cars to public transportation and/or active mobility in a period of several years were analysed. For each city, an interview was conducted with a local expert. The questions focused on the reasons for successful changes in travel habits and the existence and relevance of the SUMP in bringing about these changes. The results show that all cities analysed have some form of SUMP, and many have additional, more specific documents. Most cities have been developing these documents and implementing the measures in them for many years. Furthermore, the modal shift was always the result of a combination of several push and pull measures. Cities implemented restrictive measures for cars as well as improved conditions for alternative modes of mobility and often focused on road space transformation.
\end{abstract}

\section{Introduction}

A Sustainable Urban Mobility Plan (SUMP) is a strategic plan that is developed and implemented by cities (or municipalities, regions, etc.) that aim at satisfying the mobility needs of people and businesses while ensuring better quality of life (Rupprecht Consult, 2019). The SUMP concept is widely supported by European commission. It was introduced in 2009 while the first SUMP guidelines followed in 2013. SUMPs take into account social, environmental and economic objectives, and mark a departure from the more traditional transport engineering-based approaches to developing urban transport systems, which have historically been based on the principle of "predict and provide" and infrastructure-led (Arsenio et. al, 2016; May, 2015). The process of developing a SUMP follows a participatory approach, focusing on people's needs. At the same time, it effectively tackles the challenges of climate, energy, and environment caused by transport. Cities with SUMP are achieving different success stories, many of them improving health of the residents -8 out of 10 healthiest cities have a SUMP (Healthiest Cities in the World 2018 by Spotahome, 2018).
In Slovenia, more than 80 municipalities in which three quarters of the country's population live, have adopted the SUMP. This laid the foundations for sustainable urban mobility planning at the local level. The analysis of the experience with SUMPs in Slovenia carried out by the Urban Planning Institute of the Republic of Slovenia showed that SUMPs of Slovenian municipalities are according to Jones's (2014) theory at the first stage of development and their measures have little impact on changing travel habits (Plevnik et al., 2020). The study also showed that no major shift in residents' travel habits was achieved with this first generation of SUMPs. Additional information was needed to show that the right selection of measures could not only provide economic benefits to the local communities (Bartle and Shergold, 2016), but also visibly change the residents' travel habits in short to midterm time frame. Therefore, a study was implemented analysing the European cities, which have achieved major changes in travel habits in a short time. It focused on the key measures that contributed most to the modal shift. The paper presents the key results of this study. 


\section{Methods}

The analysis included European cities, which have managed to achieve a major change in travel habits with increasing sustainable modes of travel at the expense of car transport in the recent years.

Firstly, we gathered information on cities' modal split from various sources on the internet, mostly from the cities' websites and strategic documents, including SUMPs. The range of the cities researched is diverse,

from capitals to smaller cities (in alphabetical order): Edinburgh, Freiburg, Ghent, Leuven, Lund, Malmö, Pontevedra, Trondheim, Vienna, and Vitoria Gasteiz. In these cities the share of car use has reduced on average from just under $50 \%$ to around $35 \%$ in a period of several years. It means that on average the share of car use has lowered for around $29 \%$.

Table 1. Cities in the analysis and their respective data.

\begin{tabular}{|c|c|c|c|c|c|c|}
\hline $\begin{array}{c}\text { Cities } \\
\text { (alphabetical order) }\end{array}$ & $\begin{array}{c}\text { Car use } \\
\text { (before) }\end{array}$ & $\begin{array}{c}\text { Year } \\
\text { (before) }\end{array}$ & $\begin{array}{c}\text { Care use } \\
\text { (after) }\end{array}$ & $\begin{array}{c}\text { Year } \\
\text { (after) }\end{array}$ & $\begin{array}{c}\text { Period } \\
\text { before-after }\end{array}$ & $\%$ of change \\
\hline Edinburgh & $54 \%$ & 2001 & $48 \%$ & 2011 & 10 years & $-11,1 \%$ \\
\hline Freiburg & $39 \%$ & 1982 & $21 \%$ & 2016 & 34 years & $-46,2 \%$ \\
\hline Ghent & $63 \%$ & 2008 & $38 \%$ & 2018 & 10 years & $-39,7 \%$ \\
\hline Leuven & $62 \%$ & 2016 & $49 \%$ & 2019 & 3 years & $-21,0 \%$ \\
\hline Lund & $42 \%$ & 2007 & $34 \%$ & 2018 & 11 years & $-19,0 \%$ \\
\hline Malmö & $53 \%$ & 2003 & $34 \%$ & 2018 & 15 years & $-35,8 \%$ \\
\hline Pontevedra & $42 \%$ & 1999 & $28 \%$ & 2016 & 17 years & $-33,3 \%$ \\
\hline Trondheim & $57 \%$ & 2009 & $50 \%$ & 2014 & 5 years & $-12,3 \%$ \\
\hline Vienna & $40 \%$ & 1993 & $27 \%$ & 2016 & 23 years & $-32,5 \%$ \\
\hline Vitoria Gasteiz & $36 \%$ & 2006 & $24 \%$ & 2014 & 8 years & $-33,3 \%$ \\
\hline AVERAGE & $49 \%$ & & $35 \%$ & & & $-29 \%$ \\
\hline
\end{tabular}

Source: literature review

Secondly, an interview was conducted in each city with a local expert who monitored these changes or was involved in them. The questions focused on the reasons for successful changes in travel habits in their city, and the measures that shifted their citizens from using a car to using public passenger transportation, cycling or walking. The role of the SUMPs in these changes was also examined.

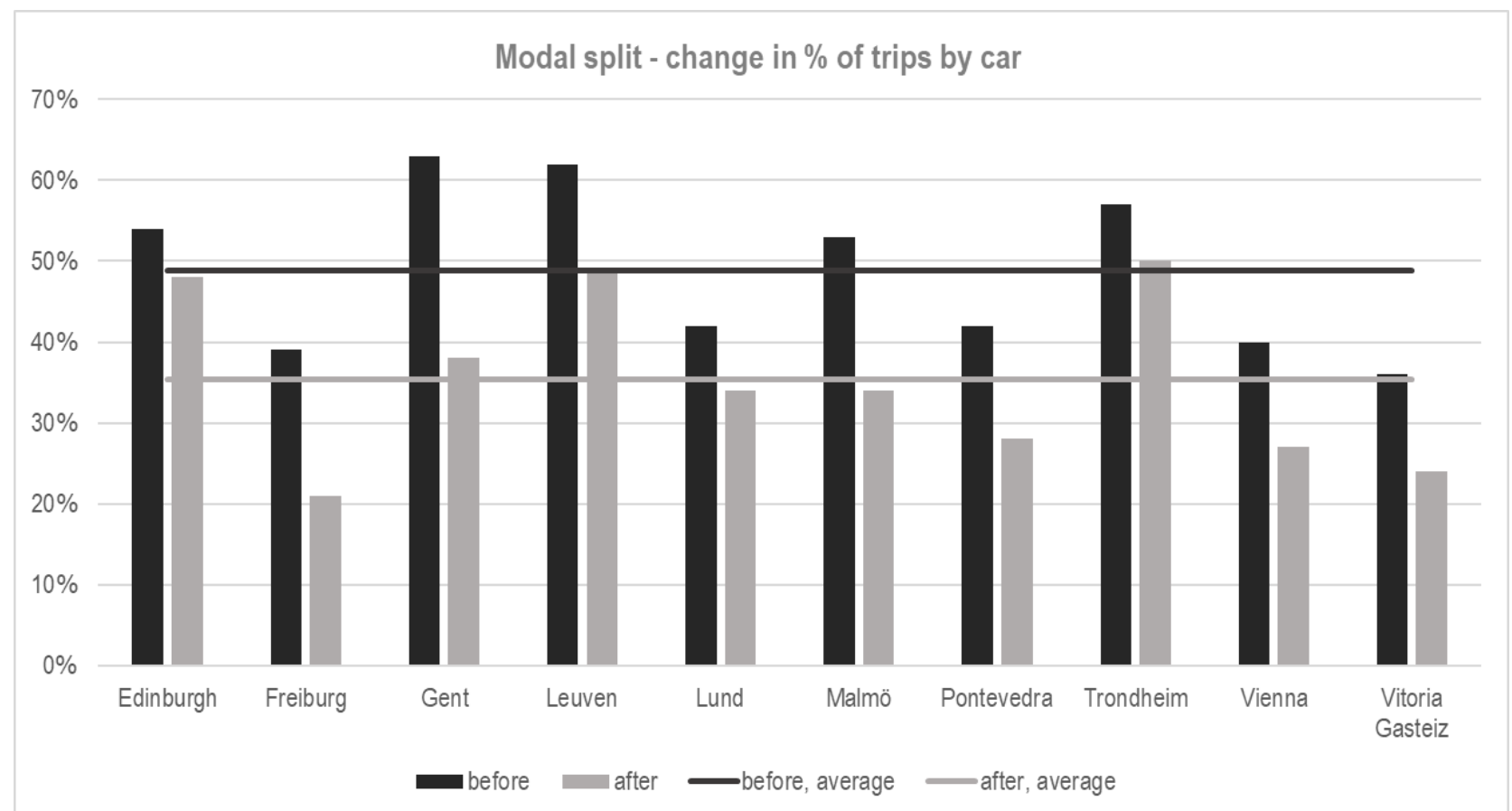

Figure 1. Modal split - change in shares of trips by car for each city Source: literature review 


\section{Results}

The results show that all the cities analysed have a SUMP or a similar strategic document in place. Many cities have also additional, more specific documents that strategically address individual travel modes, e.g., cycling strategy or parking policy. Their responses show that most cities have been developing their SUMP (or similar) for a long time and use it as a starting point for implementing ambitious and effective measures. It helps setting modal split goals and reaching those goals.

Not just one individual measure has brought about change, but combinations of measures were reported as most important driver for change. As a rule, all cities apply the "push and pull" principle. When implementing unpopular or restrictive measures they at the same thoroughly improve the conditions for alternative modes of mobility. For example, the case from Freiburg states that as push factor they implemented the following measures: higher parking fees, reduction of parking space and partial decrease of the capacity of the motorway network. On the other hand, they took care for the following pull factors: improved public transportation (especially tram tracks), improved cycling network, improved sharing services (car sharing, bike sharing). While improving the conditions for using the alternative modes they also did some marketing for environmentally friendly traffic modes to let people know that improvements have been made.

All the successful cities have the same principle in common - restraining car traffic and improving all the alternative modes, many of them focusing on public transportation, and also on improving conditions for cycling and walking.

The approach that encapsulates the majority of implemented measures in the cities researched is the road space transformation which can be a push and pull approach itself. It usually takes up space from cars, reduces their speed, and at the same time provides the infrastructure for sustainable alternatives in this space. It is implemented with comprehensive measures, such as comprehensive traffic calming, parking management, establishment of friendly traffic areas, thorough reorganization of public transport, dense cycling network, fast cycling connections, etc.

\section{Discussion}

The results from all the cities point in the same direction. The cities need to develop and implement SUMP (or similar) to set up the foundation for successful modal shift. Additional more specific documents can also be beneficial when trying to improve conditions for a specific travel mode.
Unpopular or restrictive measures need to be implemented together with providing the infrastructure for sustainable modes of mobility to enable the change of travel habits.

One important thing that has been highlighted in the interviews and could be further explored is the importance of political support since it can be a decisive condition for making progress.

There have been some measures implemented in several Slovenian cities, but not as a comprehensive approach with all sufficient push and pull measures that would make a significant shift from car use to other more sustainable modes. For example, some restrictions for cars have been implemented, but no sufficient improvements have been made to provide better experience of public transport or cycling as competitive modes to car use.

In our opinion any city or town, regardless of the mentality of its citizens, can be successful in modal shift if there is a comprehensive approach of both, push and pull measures. Experience shows, that when people are given a realistic and efficient alternative to car use, they will use it, especially if car use is restrained. To succeed in this, the key element is also the political will since without it, SUMP (or similar) document cannot be prepared and implemented. The same applies for the measures that should be implemented to achieve the actual modal shift.

The results of the research can be used as a recommendation for cities with large share of car use which are starting or struggling with changing their modal split in favour of public transportation and active mobility. The experience from successful European cities presented here was also included in new National guidelines for the preparation of municipal SUMP in Slovenia. It is expected that the new generation of SUMPs in Slovenian municipalities will be set much more ambitiously and that their implementation will contribute to a quicker modal shift towards sustainable travel modes. 


\section{References}

[1] Arsenio, E., Martens, K., \& di Ciommo, F. (2016). Sustainable urban mobility plans: Bridging climate change and equity targets? Research in Transportation Economics, 55, 30-39. https://doi.org/10.1016/j.retrec.2016.04.008

[2] Bartle, C., Shergold, I (Ed.). (2016). The Economic Benefits of Sustainable Urban Mobility Measures: Independent Review of Evidence: Summaries. European Platform on Sustainable Urban Mobility Plans. European Commission, Brussels.

https://www.eltis.org/sites/default/files/report_sum mary_reviews_of_measures.pdf

[3] Healthiest Cities in the World 2018 by Spotahome.

Https://Www.Spotahome.Com/Healthiest-Cities-

World. Retrieved August 30, 2021, from https://www.spotahome.com/healthiest-citiesworld

[4] Jones, P. (2014). The evolution of urban mobility: The interplay of academic and policy perspectives. IATSS Research, 38(1), 7-13. https://doi.org/10.1016/j.iatssr.2014.06.001

[5] May, A. D. (2015). Encouraging good practice in the development of Sustainable Urban Mobility Plans. Case Studies on Transport Policy, 3(1), 311.

https://doi.org/10.1016/j.cstp.2014.09.001

[6] Plevnik, A., Mladenovič, L., Balant, M., Hudoklin, A. (2020). Analiza stanja Celostnega prometnega načrtovanja na lokalni ravni, presented at the Ministry of Infrastructure of the Republic of Slovenia.

[7] Rupprecht Consult (Ed). (2019). Guidelines for Developing and Implementing a Sustainable Urban Mobility Plan, Second Edition. European Commission,

Brussels. https://www.eltis.org/sites/default/files/sump_guid elines_2019_interactive_document_1.pdf 